\title{
Hazel Grouse occurrence in fragmented forests: habitat quantity and configuration is more important than quality
}

\author{
Eukasz Kajtoch • Michał Żmihorski • \\ Zbigniew Bonczar
}

Received: 17 June 2011/Revised: 25 November 2011/ Accepted: 13 April 2012/Published online: 2 June 2012

(C) The Author(s) 2012. This article is published with open access at Springerlink.com

\begin{abstract}
Forest fragmentation has led to a decline in the population of many forest specialists, especially those with limited dispersal abilities. However, some of these species also occur in fragmented forests, and their response to fragmentation is crucial to understand the impact of this process in maintaining forest biodiversity. The objective of this study was to investigate the effects of habitat quality, quantity and configuration on the occurrence of Hazel Grouse as the model species. Studies were performed in the Carpathian Foothills $\left(900 \mathrm{~km}^{2}, 15 \%\right.$ forested). Between 2000 and 2010, Hazel Grouse were detected in 25 out of 53 forest patches with high repeatability over time. Among the indices of habitat quality, the most important factors were the presence of bilberries, clearings and pioneer trees. Greater number and length of valleys also had a positive effect on the occurrence of grouse. All habitat quantity and landscape configuration variables influenced the presence of grouse positively (related to forest connectivity) or negatively (related to forest isolation). Among the explanatory variables considered, habitat quantity and landscape variables were much more important in explaining the occurrence of Hazel Grouse than variables
\end{abstract}

Communicated by G. Brazaitis.

Ł. Kajtoch $(\bowtie)$

Institute of Systematics and Evolution of Animals, Polish

Academy of Sciences, Sławkowska 17, 31-016 Kraków, Poland

e-mail: kajtoch@isez.pan.krakow.pl

M. Żmihorski

Museum and Institute of Zoology, Polish Academy of Sciences, Wilcza 64, 00-679 Warsaw, Poland

Z. Bonczar

Faculty of Animal Science, University of Agriculture,

Mickiewicza 24/28, 30-059 Kraków, Poland related to habitat quality. The study shows that habitat acreage and its connectivity are crucial for the conservation and management of Hazel Grouse populations in fragmented landscapes, and therefore, it is necessary to sustain wooded corridors between larger forest patches.

Keywords Bonasa bonasia · Isolation · Dispersion · Forest fragmentation · Foothills · Carpathians

\section{Introduction}

Forest fragmentation and the isolation of habitats are among the most important processes threatening forest biodiversity (Reed 2004; Watling and Donnelly 2006). These processes act mainly through 2 factors: (1) the spatial configuration of the landscape structure (structural fragmentation) and (2) perception of surroundings by individuals and their ability to disperse (functional fragmentation). Fragmentation may lead to the extinction of populations due to decreasing genetic variation, inbreeding depression and/or stochastic ecological events (Gutzwiller 2002). A patchy distribution of suitable habitats could be the main reason why a regional population consists of several sub-populations connected by migration, with regional dynamics being driven by local extinction and re-colonization events. Such a network of sub-populations is characterized as a typical metapopulation (Hanski and Gilpin 1997) or populations in source-sink dynamics (Pulliam 1988). Connectivity between sub-populations is a crucial factor for the existence of a metapopulation over time (Schumaker 1996), although other factors (such as birth/death rates, patch quality and predation) also influence turnover in a metapopulation.

The effects of fragmentation and landscape configuration in general have a diversified impact on particular 
organisms. In terms of fragmentation and isolation, habitat specialists with low dispersal abilities seem to be the most vulnerable (Rolstad 1991). In sedentary species, separated subpopulations are connected primarily through juvenile dispersal (Fahrig and Merriam 1994; Lidicker 2002), and even small gaps in a continuous habitat area can seriously affect the utilization of space by such organisms (Creegan and Osborne 2005). Consequently, forest-dwelling specialists are often seriously threatened, especially in regions where landscape transformation and forest fragmentation are well advanced. In the present study, we investigated the spatio-temporal variability of one such species, the Hazel Grouse Bonasa bonasia (L., 1758), inhabiting strongly fragmented forests adjacent to extensive Carpathian wooded areas.

The Hazel Grouse is a sedentary, territorial, forest-specialist bird (Bergmann et al. 1982), whose characteristics make it an interesting biological model for studying the influence of forest fragmentation on the occurrence of forest-linked species. The Hazel Grouse is a small grouse species mainly inhabiting mixed or coniferous forests, with some proportion of deciduous trees in the Eurasian Boreal belt and (originally) the temperate forest belt (Bergmann et al. 1996). In Central Europe, the distribution of Hazel Grouse is largely restricted to mountain regions (e.g. Bergmann et al. 1996; Klaus and Bergmann 2004), which probably function as an important source of colonizers for the surrounding lowland areas (Kucera 1975, De Franceschi 1994, Montadert and Leonard 2006). Foothills and uplands located between large forests at higher altitudes in the mountains (e.g. the Alps and Carpathians) and lowland forests in the Central European plain are narrow zones that consist of fragmented and isolated forests, located within an open land matrix. These zones probably act as one-way corridors facilitating the expansion of the Hazel Grouse into the lowlands.

Hazel Grouse populate the early seral stages of forests: areas disturbed naturally (e.g. resulting from fires, snow breaks, avalanches, windfalls), anthropogenically (regrowths, overgrowing clearings and abandoned land) (Scherzinger 1976) and areas of rejuvenation embedded in old-growth forests (Swenson 1995; Sachot et al. 2003). The habitat and landscape requirements of the Hazel Grouse have been investigated in several studies in the boreal and temperate forests of Fennoscandia, Central Europe and Asia (e.g. Åberg et al. 2003; Sun et al. 2003; Rhim 2006; Müller et al. 2011). Almost all studies were performed in different types of continuous forests (where suitable patches were located inside a forest matrix), but only a few of them have concentrated on the distribution of the Hazel Grouse in forests situated in an open land matrix (Åberg et al. 1995; Saari et al. 1998; Klaus and Sewitz 2000; Sun et al. 2003). Our research addresses this last issue, albeit in a somewhat different way. We attempt to use data from a large area consisting of diversely sized forest patches located in an open land matrix (but connected via wooded corridors) to select factors influencing the occurrence of grouse in such a network. Moreover, we chose an area (Carpathian Foothills) where forests cover only about $15 \%$ of the land, which is considerably less than the $32 \%$ deemed by Saari et al. (1998) to be the threshold value below which the effects of habitat fragmentation act against the presence of the Hazel Grouse.

The Hazel Grouse is generally considered to be sedentary in Europe (Bergmann et al. 1982). In continuous or connected forests, juvenile individuals can disperse up to $10-25 \mathrm{~km}$. (Kirikov in Johnsgard 1983; Montadert and Leonard 2006), although the range of the distances they move usually ranges from 0.5 to $5 \mathrm{~km}$ (Åberg et al. 1995, 1996; Montadert and Leonard 2006). This species avoids open areas (Swenson 1991a; Rhim 2006; Åberg et al. 1995; Klaus and Sewitz 2000), although occasionally it can cross non-forested gaps of $100-370 \mathrm{~m}$ (Åberg et al. 1995; Saari et al. 1998; Klaus and Sewitz 2000).

Identification of habitat and landscape factors restricting the distribution of Hazel Grouse in forest fragments located in an open land matrix is important for protecting this species. The Hazel Grouse is declining in numbers and shrinking its range and has even become extinct in many parts of its distributional range. This is primarily due to habitat disturbances caused by human activities, including forest management, where the trend is towards creating uniform stands with shrub removal, as well as the fragmentation of hitherto large forested areas, which have subsequently become open lands. The Hazel Grouse is endangered throughout Europe (Swenson and Danielson 1991; Storch 2000), listed in the Appendix of the European Birds Directive (2009/147/EC) and mentioned in Appendix 3 of the Bern Convention. It is classified as a vulnerable species in Alpine countries (Keller et al. 2001) and is included in the Polish Red List of Threatened Animals (Głowaciński 2002). It also continues to be a game bird in Poland. Hazel Grouse is considered a keystone species for old-growth forests, an umbrella species for old-growth forest species assemblages and is a good indicator for measuring the intensity of forestry. Recognizing the threshold factors for Hazel Grouse conservation in managed forests can be very helpful in planning the management and conservation of suitable habitats, for semi-natural forest assemblages and the ecological corridors connecting them.

We assumed that the population of the Hazel Grouse in forest fragments faces 2 main problems: (1) low habitat availability together with patch configuration in an unsuitable matrix and (2) restricted habitat quality. The 
amount of habitat and level of patch isolation are crucial for a population to persist over time, as well as for effective dispersal and (re)colonization of suitable patches. However, as the species is associated with specific forest microhabitats, habitat quality should also be taken into account when interpreting the spatio-temporal dynamic of the Hazel Grouse population. The main purpose of this study was to investigate the effects of these 2 types of factors on the occurrence and dynamics of Hazel Grouse.

\section{Methods}

\section{Study area}

The fieldwork was conducted in a landscape consisting of forest fragments located in an open land matrix, about $900 \mathrm{~km}^{2}$, situated in southern Poland (midpoint $\left.49^{\circ} 52^{\prime} 17.6^{\prime \prime} \mathrm{N}, 20^{\circ} 15^{\prime} 24.2^{\prime \prime} \mathrm{E}\right)$. The study area covered part of the Wieliczka-Wiśnicz Foothills and is located between the mountains (Carpathians) in the south and lowlands in the north (Kondracki 2000) (Fig. 1). These foothills consist of many hills (300-500 m a.s.1.) surrounded by valleys. About $75 \%$ of this area is covered by open land (fields and meadows), of which approx. $10 \%$ is occupied by villages or small towns together with orchards. Forests and woods cover about $15 \%$ of the total area and consist of many forest patches, totally or partially isolated from each other by open land and villages alongside roads. The dominating forest types are mixed woods with oaks Quercus spp., pines Pinus spp., beeches Fagus sylvatica, firs Abies alba, hornbeams Carpinus betulus, birches Betula spp., alders Alnus spp., willows Salix spp., spruces Picea abies and larches Larix spp. These forests are extensively managed, although some patches are semi-natural and belong to the following forest assemblages: oak forests (Luzulo
luzuloidis-Quercetum), hornbeam forests (Tilio-Carpinetum), beech forests (Dentario glandulosae-Fagetum, Luzulo luzuloidis-Fagetum), fir forests (Abietum polonicum) and pine forests (Leucobryo-Pinetum).

Most of the forest patches are located on steeper slopes and on the tops of the highest hills. Riverbanks, in and between forests, were overgrown by riparian forests (AlnoUlmion). Almost all forest patches consist of a mosaic of different types of forests and are overgrown by many tree species, especially along watercourses. Forest patches can typically be divided into 5 categories, dominated by: (1) deciduous woods (mainly with oaks, hornbeams and birches), (2) pine-oak woods, (3) beech-fir woods, (4) coniferous woods (mainly with firs, pines and larches) and (5) mixed stands (with many tree species). Forests or wooded patches differ in size from a few hectares to 1,090 ha (average of about 250 ha). The average age of the dominant stands in these patches is about 85 years (60-140 years). The distance between forest patches is in the range of $0.3-4.2 \mathrm{~km}$ (average $1.3 \mathrm{~km}$ ); however, many of these patches are connected via forested belts along valleys or across open land; $70 \%$ of forests are managed by the state forestry service, while the rest are privately owned.

The forest patch was considered independent when it was totally surrounded by non-forested land (meadows, fields, villages), and wooded corridors connecting patches were $<25 \mathrm{~m}$ wide.

Among the few dozen independent forest patches, 53 of the largest (more than 30 ha) were chosen. The objective was to exclude from the analyses those forest patches that were deemed too small to sustain at least one Hazel Grouse on its territory. Hazel Grouse territories cover a range of 10-30 ha of suitable habitat in Central Europe (Wiesner et al. 1977; Zbinden 1979; Bergmann et al. 1996). As a suitable habitat may include only a portion of the total forest area, patches smaller than 30 ha are probably too

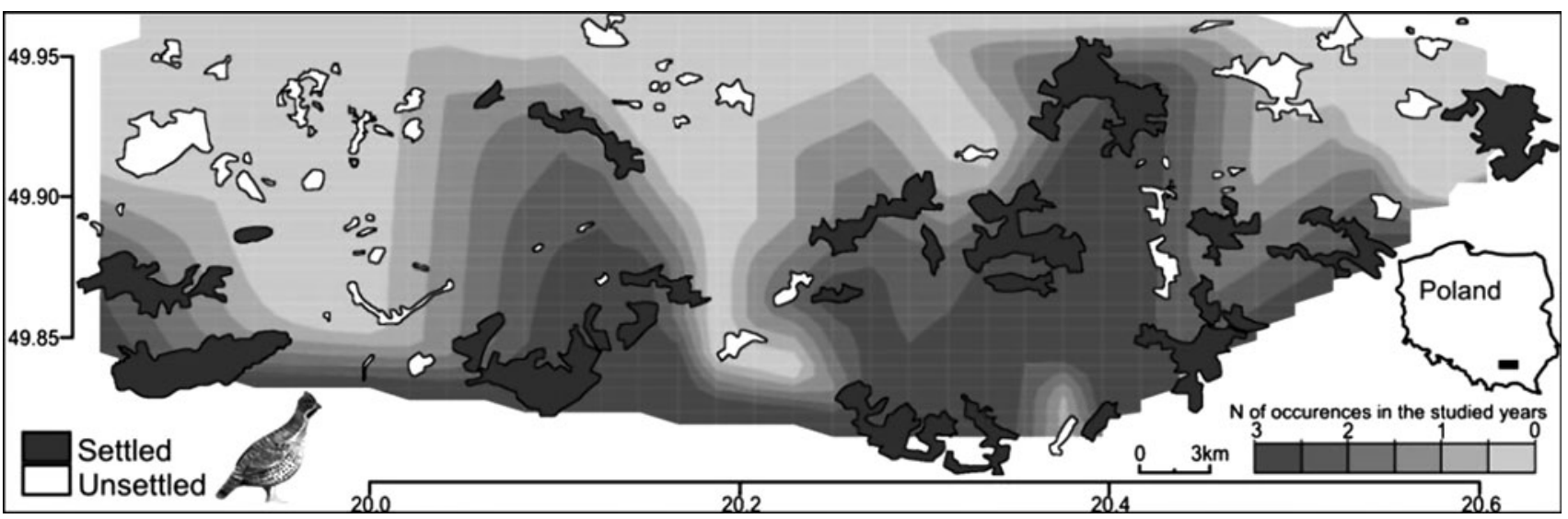

Fig. 1 Distribution of the forest patches settled and unsettled by Hazel Grouse. Gradient in the background presents averaged number of occurrences of Hazel Grouse in the study area 
small for Hazel Grouse, and indeed, these birds were never seen in forests smaller than 70 ha. Therefore, including these small forests would have led to meaningless results. However, all forest patches (even those smaller than 30 ha) were searched for the presence of Hazel Grouse (Fig. 1).

\section{Hazel Grouse censusing}

The Hazel Grouse distribution and occurrence census was conducted in the study area from 2000 to 2010 . The main census was performed from mid-March to early May. The census followed the method described by Swenson (1991b). The patches were searched for Hazel Grouse using walking transects (along forest roads, forest compartments borders and valleys). The total area of small forests $(<100 \mathrm{ha})$ was covered. Transects in larger forests were spaced approximately of $300 \mathrm{~m}$ from each other inside the forest and ran across all valleys and gorges. One or two persons were involved in each search. Every $150 \mathrm{~m}$, a pause of a few minutes was made to lure the Hazel Grouse with a whistle-pipe, hand-made from a hen bone. This distance was chosen as Hazel Grouse are heard effectively for up to $200 \mathrm{~m}$ in the rough terrain of the foothill forests (Matysek M., Kajtoch Ł., unpublished). The frequency of whistling was approximately every $30 \mathrm{~s}$. After a few minutes of listening, the observer moved on to the next point. The census was performed mainly during mornings and evenings, as Swenson (1991b) found a lower response frequency during midday, and only in good weather conditions (without heavy rain or snow and strong winds). With this method, Swenson (1991b) found a mean response accuracy of $82 \pm 7.0 \%$ for males. The responses used for luring the grouse were mostly a male's songs, but also included flutter jumping, flutter flying or a silent approach. During the time when snow was still present (up to the end of March or beginning of April, depending on the year), a bird's tracks and signs (e.g. droppings, bathing sites, sleeping snow holes and feathers) were also sought out. Moreover, most of the forest patches were also visited during a period spanning the end of May-beginning of July, and bird families (pairs or females leading nestlings) were sought in order to verify whether Hazel Grouse were breeding in the study area. As the study area was large, we performed our research in selected forest patches simultaneously every year. Each forest patch (independent forest unit) was investigated for the occurrence of Hazel Grouse during 3 non-successive years from 2000 to 2010 in 3 periods: 2000-2003, 2004-2006 and 2007-2010. Such a scheme was chosen to minimize the risk of omitting (overlooking) birds in the studied forest patches in cases of population fluctuations and changes in distribution during the study period. The coordinates of all bird observations (visual or aural), tracks and signs were located using forest maps or a GPS receiver. Patches with no noted birds, tracks or signs were considered to be absent of Hazel Grouse. Patches where birds, their signs or tracks were detected during the study period at least once were deemed to be inhabited by Hazel Grouse, and presence-absence data were used for further analyses. However, the number of records of the species in each forest was visualized with the help of a gradient map implemented in the 'akima' package in R (R Development Core Team 2010).

\section{Habitat characteristics}

Potentially important factors for the occurrence of Hazel Grouse were divided into 2 categories: (1) habitat quality factors and (2) habitat quantity and spatial configuration factors.

The following habitat quality factors were chosen: (1) OWNERSHIP-particular forest patches were ascribed to 2 categories: private forests or state (national) forests; ownership can seriously affect some characteristics of the tree stand; (2) Conifer.Regrowth-presence of fir/spruce/pine re-growth, natural or man-made, as an indicator of winter shelters for Hazel Grouse; (3) BILBERRY-presence of bilberry Vaccinium spp. as an indicator of forest habitat type and stand history of a given forest; (4) ANT-presence of ant-hills Formica spp. as places for feather cleaning; (5) PioneER.TREe - presence of alders, willows, rowans and birches as indicators of the most important winter food sources for Hazel Grouse; (6) Clearings-presence of overgrown clearings or abandoned meadows and pastures as second-best places for Hazel Grouse occurrence; (7) AGE - mean age of tree stand in a given forest; (8) $\mathrm{VAL}$ LEY.LENGTH-length of watercourse (in metres) in forested valleys; (9) VALLEY.N—number of valleys in a given forest; (10) VALLEY.PER.AREA-length of watercourse in valleys per ha in a given forest. The threshold for each factor to determine presence/absence was fixed at a level of $5 \%$, for example, a forest was considered to be bilberry-present if this shrub was detected in at least $5 \%$ of the particular forest patch area.

Habitat quantity and configuration were as follows: (11) AREA-size (area, in hectares) of a given forest, logtransformed; (12) CORRIDOR.N-numbers of wooded zones along valleys or across open lands that connected 2 forests, indicator of forest connectivity; (13) CORRIDOR.\%-width of wooded corridors joining 2 independent forests, shown as a percentage of a forest's girth; (14) ROADS—number of larger and heavily used roads with villages situated alongside, which are located between 2 given forests, indicator of forest isolation; (15) BUFFER.OPEN-frequency (\%) of open land and urbanized areas in a $500 \mathrm{~m}$ radius from a given forest edge, indicator of forest isolation; (16) DisT.FOREST-distance from a given forest (in kilometres) 
to the nearest neighbouring forest, indicator of a forest's isolation; (17) DIST.FOREST.GROUSE-distance from a given forest (in kilometres) to the nearest forest inhabited by Hazel Grouse, log-transformed.

Factors number 1, 7 and 11 were obtained from forestry maps (e.g. http://rdlpkrakow.gis-net.pl/), factors 8-17 were calculated from geographic maps and aerial photographs using GIS (http://rdlpkrakow.gis-net.pl/), and factors 2-6 were checked during field inventories.

\section{Statistical analysis}

We attempted to assess the importance of variables for the distribution of the Hazel Grouse using a univariate-modelling approach. In this method, we used all the variables available and built 17 univariate generalized linear models (for each independent explanatory variable). We used a generalized linear model (GLM) with a binomial error distribution and logit-link function implemented in SPSS 16.0. We used 4 methods for evaluating the fit of the models to the data: Akaike's information criterion (AIC) with AIC weight indicating the probability that a given model is the best model; Nagelkerke pseudo $R^{2}$; an area under a receiver operating characteristic (ROC) curve; and the statistical significance of a model. For the visualization, we used redundancy analysis (RDA) implemented in CANOCO (Lepš and Šmilauer 2003), and a Monte Carlo test under 4,999 permutations for the significance assessment of the relationships between variables and the dependent variable.

For the next step, we aimed at building multivariate models explaining the occurrences of Hazel Grouse in the controlled forests. For this purpose, we checked available habitat variables for collinearity and selected 5 relatively independent variables, namely: Age, Bilberry, Valleys.Per.Area, Area, and Dist.Forest.Grouse. Moreover, we combined 5 other variables (Dist.Forest, BufFer.Open, RoAds, Corridor.N, and Corridor.\%) into one component with the help of the principal component analysis (PCA). The extracted component (hereafter referred to as IsOLATION) ranged from -2.34 to 1.87 (mean 0.00, $\pm 1.00 \mathrm{SD}$ ) and explained $73.8 \%$ of the variance of the 5 original variables (eigenvalue 3.69), whereas its biological importance corresponds to habitat isolation. Forests characterized by positive values of the component were isolated from the remaining forests, whereas forests characterized by negative values were well connected with other patches. As a consequence, we obtained 6 habitat characteristics that were relatively independent (Spearman's rho ranged from 0.799 to 0.028 and the variation inflation factor ranged from 1.042 to 3.979 ).

We used the 6 variables as explanatory variables in our modelling and a generalized linear model (GLM) with binomial error distribution and a logit-link function implemented in SPSS 16.0 to explain the sightings (present vs. absent) of Hazel Grouse in controlled forests on the basis of combinations of the 6 variables. We used the information theoretic approach based on Akaike's information criterion to rank the models (Johnson and Omland 2004). Prior to the analysis, we proposed three sets of competing models: 6 models based only on habitat quality (hereafter known as habitat quality models), 7 models related to habitat quantity and configuration (hereafter termed landscape models) and 4 combined models. Additionally, we used an intercept-only model for controlling the performance of all remaining models. For each model, we computed the AIC value, and on this basis, we predicted the fit of particular models. Next, we used model averaging to estimate the effect size of the 6 explanatory variables. We plotted the bivariate response surface to visualize the most important effects with the help of the LR-mesh programme (Rudner 2004).

\section{Results}

\section{Hazel Grouse occurrence}

Hazel Grouse were detected in 25 out of 53 of the independent forest patches studied. Hazel Grouse (or their tracks or signs) were never observed in 28 forest patches. Hazel Grouse were also not detected in forest patches smaller than 30 ha. Pairs or hens leading nestlings were observed only on a few occasions. These birds were detected in a similar frequency in all types of forests except pure deciduous stands (Fig. 2). Hazel Grouse inhabited all

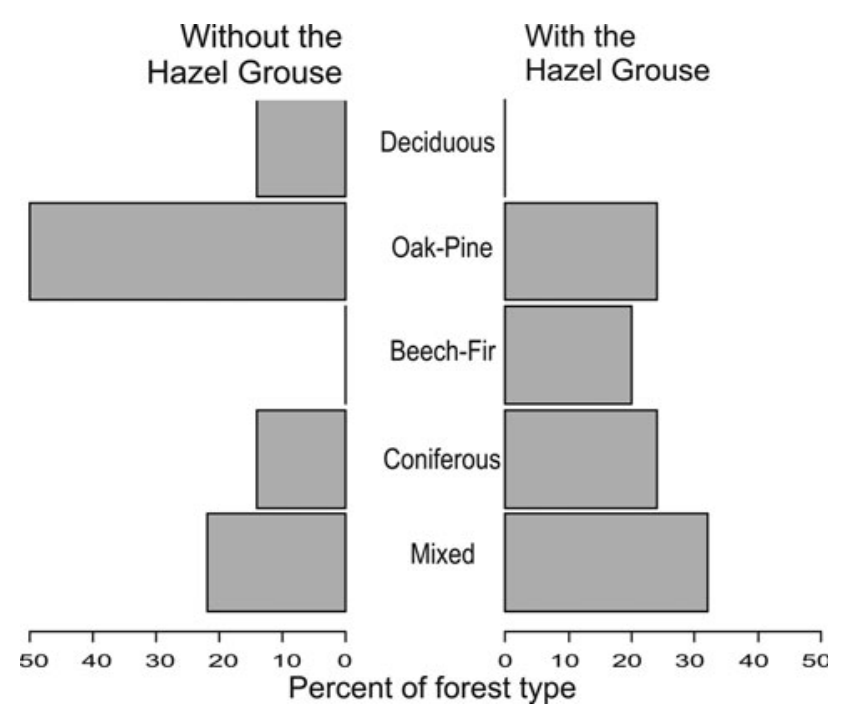

Fig. 2 Frequency of 5 types of forests with Hazel Grouse present and absent during the study period 
beech-fir forests and were detected 1.5-1.7 times more often in coniferous forests and mixed forests, while being observed in oak-pine forests at approximately half that number (Fig. 2). Grouse detectability was at a similar level during 3 non-consecutive years. When taking the 25 occupied forest patches during the study period $(100 \%)$, grouse detection in following years of the census were detected at rates of 88,76 and $84 \%$, respectively. Hazel Grouse were observed in all census years in $60 \%$ of occupied forest patches, in $84 \%$ during 2 years and in $16 \%$ of occupied forest patches in only 1 year. We recorded a high repeatability of result from particular forests over time, and the results from different controls for particular forest were highly correlated $(r=0.73-0.81)$. If the species was recorded in a forest during the first period of the study, it was also observed in the second ( $82 \%$ of cases) and the third ( $82 \%)$ periods. This pattern of detectability suggests that most of the occupied forest patches were actually occupied during the entire study period and only a small portion was inhabited ephemerally.

All values of the studied variables and their differences for forests with and without grouse are presented in Table 1.

\section{Univariate models}

Only 3 out of 17 habitat variables appeared to be a nonsignificant predictor of the occurrence of Hazel Grouse.
However, the importance of the remaining 14 was highly diversified.

According to the information theoretic approach, as well as the pseudo $R^{2}$, the number of corridors (CORRIDOR.N) best explained the frequency of Hazel Grouse in the studied forests. Also, the area under the ROC curve confirmed the importance of this variable, although the distance to the nearest forest with grouse was slightly better fitted to the data according to the AUC criterion. In general, variables related to habitat quality were much weaker predictors (variables 1-10 in Table 2) compared to habitat quantity and landscape variables (11-17). The cumulative AIC weight of the models using habitat quality variables denoted 0.0005 , whereas for the models using habitat quantity and landscape variables, the analogous value was 0.9995 . Therefore, it was highly unlikely that the best model among the set of 17 competing, univariate models was the habitat quality model. However, among the habitat quality variables, VALLEYS.LENGTH and VaLLEYs.N appeared to be the most informative, although this probably results from the strong collinearity of the 2 variables with forest area (AREA) (see Fig. 3). It is worth noting that the length of the valleys computed per area of forest was of little importance in explaining Hazel Grouse occurrence and was insignificant (Table 2). Also, the Conifer.Regrowth, BILBERRY and ANT variables adequately explained the occurrence of Hazel Grouse.

Table 1 Basic characteristics and description of the habitat variables used in modelling

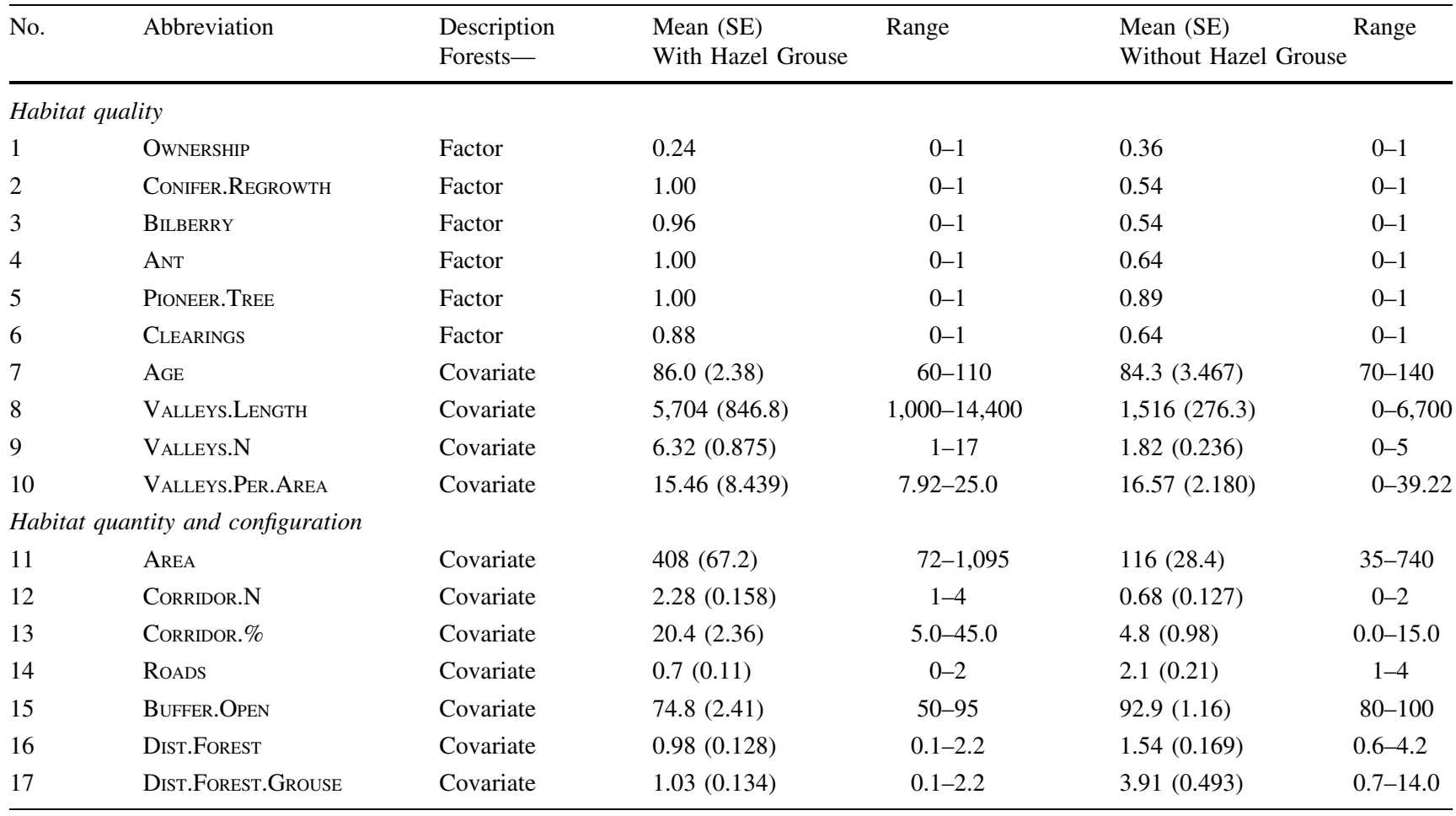


Table 2 Performances of 17 univariate logistic regression models explaining the occurrence of the Hazel Grouse in the 53 studied forests

For each model, Akaike's information criterion (AIC) with Akaike weight computed for the set of 17 models $(w)$,

Nagelkerke pseudo $R^{2}$, area under a receiver operating characteristic curve (AUC) and statistical significance $(P)$ are listed. Variables used for further modelling are typed in bold

\begin{tabular}{|c|c|c|c|c|c|}
\hline & Predictor & $\operatorname{AIC}(w)$ & $R^{2}$ & AUC & $P$ \\
\hline 1 & OWNERSHIP & $76.44(0.00)$ & 0.022 & 0.559 & 0.3516 \\
\hline 2 & CONIFER.REGROWTH & $56.93(0.00)$ & 0.426 & 0.732 & 0.0000 \\
\hline 3 & BILBERRY & $63.18(0.00)$ & 0.312 & 0.712 & 0.0002 \\
\hline 4 & AnT & $62.47(0.00)$ & 0.326 & 0.679 & 0.0001 \\
\hline 5 & Pioneer.Tree & $73.32(0.00)$ & 0.097 & 0.554 & 0.0458 \\
\hline 6 & Clearings & $73.10(0.00)$ & 0.102 & 0.619 & 0.0402 \\
\hline 7 & Age & $77.14(0.00)$ & 0.004 & 0.576 & 0.6855 \\
\hline 8 & VALLEYS.LENGTH & $53.80(0.00)$ & 0.478 & 0.881 & 0.0000 \\
\hline 9 & VALLEYS.N & $50.49(0.00)$ & 0.530 & 0.861 & 0.0000 \\
\hline 10 & Valleys.Per.Area & $77.09(0.00)$ & 0.005 & 0.511 & 0.6445 \\
\hline 11 & Area & $52.64(0.00)$ & 0.365 & 0.864 & 0.0000 \\
\hline 12 & CORRIDOR.N & $35.63(0.70)$ & 0.727 & 0.929 & 0.0000 \\
\hline 13 & CORRIDOR. $\%$ & $42.74(0.02)$ & 0.640 & 0.908 & 0.0000 \\
\hline 14 & ROADS & $47.53(0.00)$ & 0.574 & 0.853 & 0.0000 \\
\hline 15 & BUFFER.OPEN & $39.63(0.09)$ & 0.679 & 0.924 & 0.0000 \\
\hline 16 & Dist.FoREST & $39.26(0.11)$ & 0.160 & 0.701 & 0.0046 \\
\hline 17 & Dist.Forest.Grouse & $40.32(0.07)$ & 0.720 & 0.941 & 0.0000 \\
\hline
\end{tabular}

Fig. 3 Relationships between the occurrence of Hazel Grouse and explanatory variables revealed by the redundancy analysis (RDA)

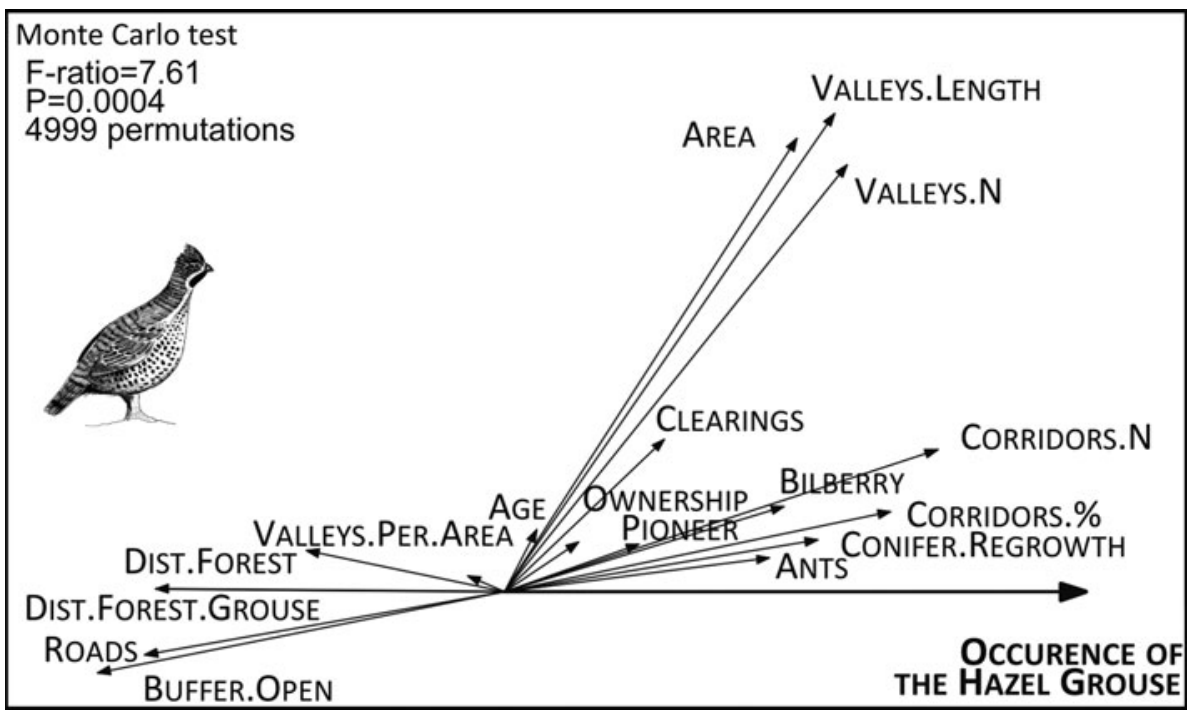

Multivariate models

In general, the univariate models were distinctly less supported by the data compared to the multivariate models. In the set of landscape models (models no. 8-14), those using only 1 variable (8-10) were much less informative compared to the 4 remaining ones that used 2 or 3 variables (Table 3). However, this pattern is less clear in the set of habitat quality models, as the most parsimonious model in this set was the univariate one (model no. 3 ).

We recorded a similar pattern as in the univariate approach: models using habitat quality characteristics were significantly less informative than models using habitat quantity and landscape variables. The cumulative AIC weight for the set of 6 habitat quality models (2-7) was close to zero, whereas the analogous value for the set of landscape models exceeded 0.5. Combined models (i.e. models using both habitat quality variables as well as habitat quantity and landscape variables) also fitted the data on the distribution of Hazel Grouse well. However, this relatively good fit of the combined models was driven by habitat quantity and landscape variables. This suggestion is supported by the fact that model no. 14 was more parsimonious compared to model 15 , 16 and 17, which indicates that the inclusion of habitat quality variables into the landscape models decreases the parsimony of the final models (Table 3).

Parameter averaging confirmed that the effect of habitat quantity and the landscape context of the surveyed forest 
Table 3 Set of competing generalized linear models with binomial error distribution and logit-link function explaining the occurrence of the Hazel Grouse in 53 forests on the basis of 6 predictors described in the "Methods" section (see Table 1)

\begin{tabular}{|c|c|c|c|c|c|}
\hline No. & Model & $k$ & AIC & $\Delta \mathrm{AIC}$ & $w$ \\
\hline \multirow[t]{2}{*}{1} & Intercept only & 0 & 75.30 & 43.57 & 0.000 \\
\hline & Habitat quality models & & & & \\
\hline 2 & AGE & 1 & 77.14 & 45.40 & 0.000 \\
\hline 3 & BILBERRY & 1 & 63.18 & 31.44 & 0.000 \\
\hline 4 & VALLEYS.PER.AREA & 1 & 77.09 & 45.35 & 0.000 \\
\hline 5 & AGE + BILBERRY & 2 & 65.16 & 33.43 & 0.000 \\
\hline 6 & Bilberry + Valleys.Per.Area & 2 & 65.17 & 33.44 & 0.000 \\
\hline \multirow[t]{3}{*}{7} & Age + Bilberry + Valleys.Per.Area & 3 & 67.16 & 35.43 & 0.000 \\
\hline & & & & & $\Sigma=0.000$ \\
\hline & Landscape models & & & & \\
\hline 8 & AREA & 1 & 52.64 & 20.90 & 0.000 \\
\hline 9 & ISOLATION & 1 & 36.25 & 4.51 & 0.023 \\
\hline 10 & Dist.Forest.Grouse & 1 & 40.32 & 8.59 & 0.003 \\
\hline 11 & Isolation + Dist.Forest.Grouse & 2 & 33.58 & 1.85 & 0.088 \\
\hline 12 & Area + Isolation & 2 & 35.42 & 3.68 & 0.035 \\
\hline 13 & AreA + Dist.Forest.Grouse & 2 & 31.74 & 0.00 & 0.221 \\
\hline \multirow[t]{3}{*}{14} & Area + Isolation + Dist.Forest.Grouse & 3 & 31.86 & 0.12 & 0.208 \\
\hline & & & & & $\Sigma=0.578$ \\
\hline & Combined models & & & & \\
\hline 15 & Isolation + Dist.Forest.Grouse + Area + Bilberry & 4 & 31.98 & 0.24 & 0.196 \\
\hline 16 & Isolation + Dist.Forest.Grouse + Area + Age & 4 & 33.58 & 1.84 & 0.088 \\
\hline 17 & Isolation + Dist.Forest.Grouse + Area + Valleys.Per.Area & 4 & 33.68 & 1.95 & 0.084 \\
\hline \multirow[t]{2}{*}{18} & Isolation + Dist.Forest.Grouse + Area + Age + Bilberry + Valleys.Per.Area & 6 & 34.55 & 2.81 & 0.054 \\
\hline & & & & & $\Sigma=0.422$ \\
\hline
\end{tabular}

The number of predictors $(k)$, the Akaike's information criterion score (AIC), the difference between the given model and the most parsimonious model $(\Delta)$ and Akaike weight $(w)$ are listed for each model

were much more important for Hazel Grouse occurrence compared to the effect of habitat quality (Table 4). Distance to the nearest forest settled by Hazel Grouse appeared to be the most important variable: the chance that the Hazel Grouse was present in a given forest changed 500,000 times depending on the distance from a given forest to the nearest forest with grouse. The effect of isolation was also very important for the occurrence of Hazel Grouse. The area of a forest patch changed the chance of grouse occurrence approximately 50 times (Table 4).

The occurrence of Hazel Grouse was highest for those forests well connected to other forests and located close to other forests containing Hazel Grouse (Fig. 4).

\section{Discussion}

Population in a fragmented habitat

The occurrence of Hazel Grouse in highly fragmented and isolated forest patches located in a landscape of open land seemed to contradict the habitat preferences for this species. Hazel Grouse almost exclusively inhabit the large and continuous forests of the Eurasian Boreal belt and, formerly, mixed forests in the temperate zone, where presently they are found most often in mountain areas (Bergmann et al. 1996; Klaus and Bergmann 2004). Populations of Hazel Grouse in open land (e.g. agricultural) landscapes were reported only from China (Åberg et al. 1995), the Czech Republic (Klaus and Sewitz 2000) and Scandinavia (Saari et al. 1998; Sun et al. 2003). At least in Sweden and the Czech Republic, there are satellite locations in the vicinity of larger (continuous) forests inhabited by Hazel Grouse, and these birds probably appeared there during dispersion and do not breed in smaller forest patches inside the open land matrix. Similarly in the French Alps, Finland and Asia, juvenile grouse can disperse over long distances, crossing even larger forests gaps (Kirikov in Johnsgard 1983; Fang and Sun 1997, Montadert and Leonard 2006). Fragmented forests in an open land matrix are a characteristic landscape for the Carpathian Foothills (Kondracki 2000). In that narrow zone (50-100 km width) 
Table 4 Averaged parameter estimates of the 6 explanatory variables explaining occurrences of the Hazel Grouse in 53 forests

\begin{tabular}{lrll}
\hline Variable & \multicolumn{1}{l}{ B } & Exp (B) & Exp (B*range) \\
\hline AGE & -0.006 & 0.994 & 0.619 \\
BILBERRY = present & 0.616 & 1.851 & 1.851 \\
VALLEYS.PER.AREA & 0.008 & 1.008 & 1.369 \\
AREA & 1.130 & 3.096 & 48.764 \\
IZOLATION & -1.475 & 0.229 & 0.0020 \\
DisT.FOREST.GROUSE & -2.628 & 0.072 & 0.000002 \\
\hline
\end{tabular}

AIC weight (w) presented in Table 3 was used as a weight in model averaging

between the mountains in the south and lowlands in the north, Hazel Grouse populations were known to exist for many years (Wiltowski 1966; Jamrozy 1991; Bonczar 1992; Kajtoch 2002, Kajtoch and Piestrzyńska-Kajtoch 2006; Kajtoch et al. 2011). The status of these birds is not certain and they may be sedentary breeders or nomadic subpopulations. The scarce observations of Hazel Grouse families in the study area, as well as the breeding status of these birds in the eastern foothills (Hordowski 1999), suggest that these subpopulations, at least in larger forests, are actually breeding. On the other hand, only single birds were detected in some of the studied forests, without any evidence of nesting. The most probable scenario is a combined pattern-some subpopulations are sedentary and breeding and other locations are inhabited, albeit it only ephemerally. This is also partially confirmed by the detectability of Hazel Grouse over time. In the majority of the forests settled by the species between 2000 and 2010, it was present during this entire period, but in some patches
(16\% of forests), the species was observed only in 1 year. Fluctuations in the number of territories are common for this species (e.g. Saari et al. 1998; Cattadori and Hudson 2000). In the foothills studied, Hazel Grouse probably inhabit and breed in some years, but in others, they are too rare and sparsely distributed for breeding. Some populations may also have become extinct, with new individuals settling in the forests at a later time.

The persistence of the Hazel Grouse population in a highly fragmented landscape forces one to analyse the advantages and disadvantages of living in such a specific habitat. The disadvantages are obvious, as much research has addressed this issue (see review in Fahrig 2003), also in the case of the Hazel Grouse (Swenson 1993a, b; Saari et al. 1998; Åberg et al. 1995): edge effects, mortality during migration between patches, subpopulations vulnerable to local and temporal disturbances, etc. However, it is worth discussing the possible advantages of such a habitat configuration for the Hazel Grouse. A possible advantage of inhabiting fragmented forests in the foothills is the inaccessibility of forested valleys and ravines to people. Slopes along these valleys and ravines are very steep and rocky, and the floor is swampy, which makes forest management, hunting and harvesting wood, fruit and mushrooms unprofitable. In these places, Hazel Grouse are probably most secure. The character of forests along valleys and ravines is closest to a natural state, with many tree, shrub and herb species. There are many food sources available for grouse (buds, catkins, herbs, mosses, berries and young leaves) (Bonczar and Wróbel 1990). There are also many dead trees lying on the forest floor, which together with shrubs and herbs provide dense cover,
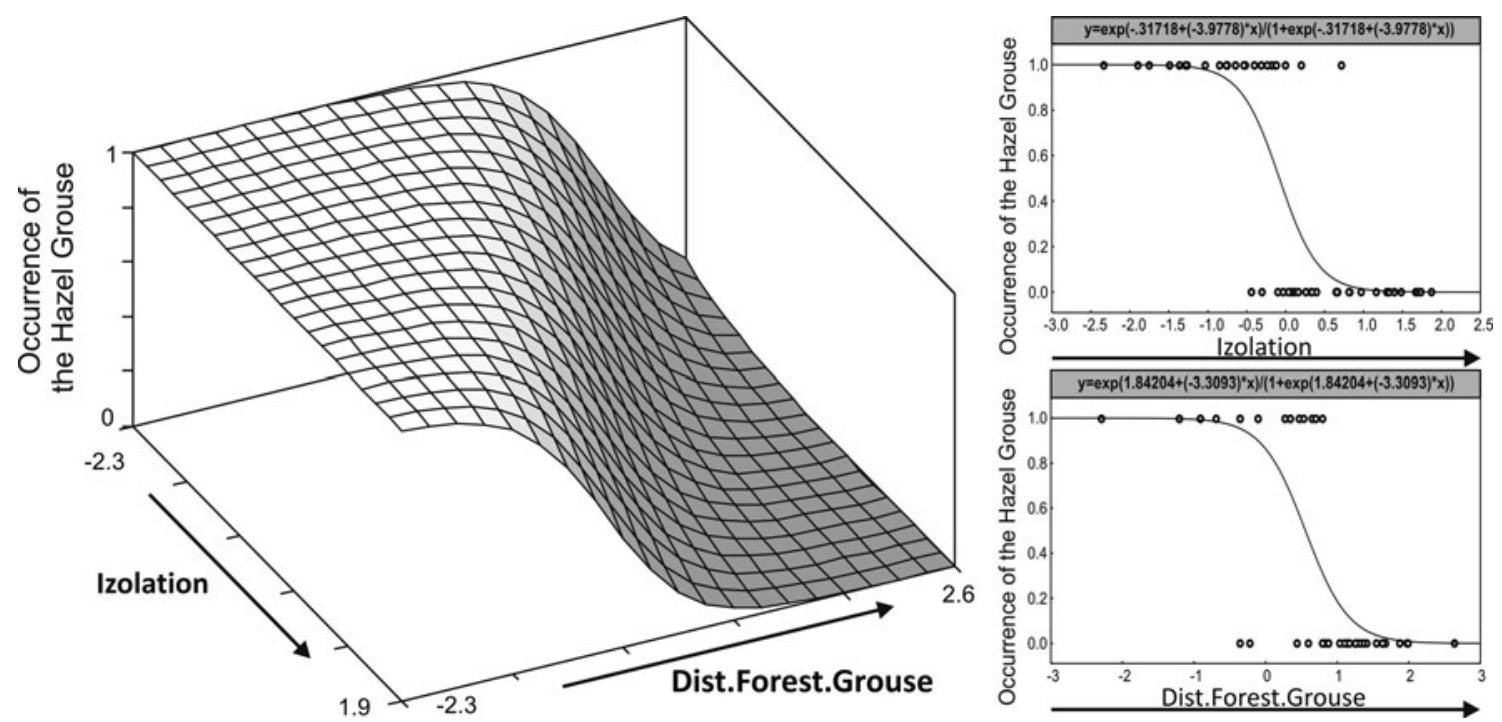

Fig. 4 Bivariate response curve and logistic fits of the two most important effects: component symbolizing isolation (IsOLATION) and distance to the nearest forest with Hazel Grouse (Dist.FoREST.Grouse) on the occurrence of Hazel Grouse in 53 studied forests in Southern Poland. Averaged parameters from Table 3 were used for the bivariate fit 
creating a highly beneficial habitat for grouse (Swenson 1995).

Finally, a probable advantage for the presence of young Hazel Grouse in a landscape consisting of forest fragments inside an open land matrix is the possibility of just surviving there while all other more suitable places in the mountains are occupied. The re-colonization of remote lowland habitats is occurring in eastern and central Europe, where Hazel Grouse have been observed in lowland forest north of the Carpathians (Martyka et al. 2002). Such a dispersion of juvenile birds outside of the mountains was also observed in the Alps and Sumava Mts., where Hazel Grouse are expanding into sub-mountain regions (Kucera 1975; De Franceschi 1994; Montadert and Leonard 2006).

The importance of habitat quality versus quantity

Among habitat quality factors, the OwnERSHIP and AgE of forests were not significant. This is somewhat surprising, since forest ownership structure in Poland markedly affects several forest characteristics (Żmihorski et al. 2010). This can be explained as the result of the distribution of 2 of the most suitable types of forest habitats for the Hazel Grouse. In state forests, Hazel Grouse occupied mostly older (seminatural) forest patches where the generation of younger trees is in the forest undergrowth. On the other hand in private forests, these birds inhabit mostly the initial stages of forests due to the intensive cutting of older woods (Kajtoch et al. 2011). Two factors-CLEARING and PioneER TREES, which significantly influence Hazel Grouse presence, are related because pioneer trees often overgrow clearings, meadows and pastures. This phenomenon is common in the study area because open lands located far from villages are often abandoned. Three other habitat quality factors (CONIFER.REgRowTHS, BILBERRIEs and ANTS) positively influencing Hazel Grouse occurrence in the fragmented landscape are often related because two, BILBERRIES and ANTS, are mostly located in conifer patches. Conifer re-growth (natural or man-made) is important for Hazel Grouse because these grouse can hide during winter only in woods with some proportion of conifer trees (especially younger ones). Snow cover in foothills is often too shallow for burrowing and does not last for the entire winter, so grouse must find other cover from predation and low temperatures. Hazel Grouse completely avoided the pure deciduous stands in the study area, which agrees with data obtained from Scandinavia (Wiesner et al. 1977; Swenson 1991a, b; Bergmann et al. 1996), but contradicts studies from central and western Europe (Glutz von Blotzheim 1973) and Korea (Rhim 2010). These discrepancies can be explained as the result of differences between continental and more mild-climate forests, where some evergreen trees and deciduous shrubs (=cover during winter period) exist. Bilberries are an important food source for grouse in autumn and early spring, and ant-hills are the main places for bathing and feather cleaning (removal of parasites). Moreover, bilberries are indicators of forest habitat continuity (Żmihorski 2011), which should also be taken into account.

Most of the factors mentioned, with the exception of ant-hills, were also found to be important for Hazel Grouse in other studies (Swenson 1995; Bergmann et al. 1996; Sachot et al. 2003; Müller et al. 2011; Schaublin and Bollmann 2011). The last habitat quality factor, namely VALLEYS (number and length), are major areas where Hazel Grouse were observed in the foothills (Kajtoch et al. 2011). The importance of forested valleys and ravines for grouse was described in the preceding section, although their significance was not reported in any of the previous studies on Hazel Grouse habitat preferences. It is probably a significant factor only in foothills and highland areas.

The habitat quantity and landscape configuration factors studied are mostly related to forest area and isolation. Hazel Grouse were found mainly in larger forests connected by many wooded corridors along watercourses and surrounded by other forest patches. An exceptionally important factor was the distance to the nearest forest where other grouse were present. Similar results were also noted in studies that considered the isolation of suitable patches inside continuous forests and especially in studies conducted in the agricultural landscape (Åberg et al. 1995; Saari et al. 1998; Klaus and Sewitz 2000; Sun et al. 2003). In these studies, it was proven that Hazel Grouse can occasionally move across open land that is from 100 to $370 \mathrm{~m}$ wide. Only radiotracked grouse in the French Alps crossed forest gaps of distances up to $1 \mathrm{~km}$. (Montadert and Leonard 2006).

On the other hand, other research showed that grouse cannot spread across open land (Rhim 2006). In fragmented forests, where particular patches are connected via wooded corridors along watercourses, Hazel Grouse were predominantly found in forests separated from one another by an average of $1 \mathrm{~km}$., although some forests were located 1.4-2.2 km apart. Similar values were noted for distances to the nearest forests with Hazel Grouse. This means that in a network of forest patches inside an open land matrix, Hazel Grouse can move over much longer distances than had been detected in agricultural landscapes, but not as far as in continuous forests (Åberg et al. 1995, 1996; Montadert and Leonard 2006). This observation fits the hypothesis that dispersal is not only a reflection of the physical ability of a species to move, but is also strongly influenced by a species' behavioural response to an apparently hostile habitat (Opdam et al. 1984; Dunning et al. 1992; Taylor et al. 1993). 
We recorded that quantity and habitat configuration was crucial for the distribution of the Hazel Grouse, whereas quality was of little importance. Models that best explain the presence of Hazel Grouse in fragmented forests include only landscape predictors: area of forest, isolation from other forests and distance to other Hazel Grouse inhabited forests. Among the combined models, the best one also includes berries (related to the presence of ant-hills and conifer re-growths). Andrén (1994) reviewed some of the empirical studies and concluded that in landscapes where more than $30 \%$ of suitable habitat remained, the total area of suitable habitat was the best predictor of the abundance and distribution of a given animal species.

Moreover, both the configuration of patches and the influence of the matrix on the occurrence of the organisms were less important in such landscapes. In the region of the study, forests cover about $15 \%$ of the total area, and the cover suitable for Hazel Grouse habitats is not more than $1 / 3$ of those forests, that is, only about $5 \%$ of the total area. Our results suggest that in fragmented forests located in an open land matrix, an important predictor for Hazel Grouse occurrence is not only a forest's area, but also the configuration of patches in an unsuitable (open and urbanized land) matrix (see: Åberg et al. 1995 and Klaus and Sewitz 2000). The minor importance of habitat quality factors can be explained by the wide tolerance for their presence in such landscapes.

\section{Implications for conservation and managing}

In planning conservation strategies for Hazel Grouse, as well as management plans for public and private forestry practices in fragmented forest landscapes, attention should also be paid to the matrix, which strongly influences the occurrence of Hazel Grouse in habitat fragments. The separation of forests by more than $1 \mathrm{~km}$ of open land can have a highly isolating effect, partially compensated for by the presence of wooded corridors. Therefore, we generally recommend that particular patches should not be separated by more than this distance. We also propose that remote forests (especially those larger than $400 \mathrm{ha}$ ) should be connected via forest edges or wooded passageways in order to support the dispersal of individual Hazel Grouse between neighbouring subpopulations and facilitate the dispersion of juvenile birds from the mountains into the lowland forests. Moreover, we propose that the preferred Hazel Grouse habitats within foothill forests should be mixed ones (preferably including deciduous pioneer trees) and of various ages (some stands juvenile and some oldgrowth). Preferably, patches should be larger than 20 ha (for a single territory) and 400 ha (for a group of territories in an independent forest unit) and contain a richer fieldlayer cover (conifers and berries).
Special attention should be paid to leaving forested valleys and ravines unmanaged. Application of the abovecited indications should be beneficial to many other forestdependent organisms and make the dispersion of individuals among their subpopulations in fragmented forest landscapes more successful. The data and conclusions presented are being implemented in conservation and management plans for Hazel Grouse populations and their habitats in Polish Special Protection Areas for birds under the Natura 2,000 network.

Acknowledgments We would like to thank Piotr Skucha for information about Hazel Grouse observations in the study area and Karol Stastny for providing access to important references. Piotr Skórka and an anonymous reviewer provided helpful comments on the first draft of this article. Barbara Przybylska kindly improved the English.

Open Access This article is distributed under the terms of the Creative Commons Attribution License which permits any use, distribution, and reproduction in any medium, provided the original author(s) and the source are credited.

\section{References}

Åberg J, Jansson G, Swenson JE, Angelstam P (1995) The effect of matrix on the occurrence of Hazel Grouse (Bonasa bonasia) in isolated habitat fragments. Oecologia 103:265-269

Åberg J, Jansson G, Swenson JE, Angelstam P (1996) The effect of matrix on the occurrence of Hazel Grouse in isolated habitat fragments. Grouse News 11:22

Åberg J, Swenson JE, Angelstam P (2003) The habitat requirements of Hazel Grouse (Bonasa bonasia) in managed boreal forest and applicability of forest stand descriptions as a tool to identify suitable patches. For Ecol Manag 175:437-444

Andrén H (1994) Effects of habitat fragmentation on birds and mammals in landscapes with different proportion of suitable habitat: a review. Oikos 71:355-366

Bergmann HH, Klaus S, Müller F, Wiesner J (1982) Das Haselhuhn Bonasa bonasia Wittenberg. [The Hazel Grouse] Lutherstadt: Die NeueBrehm-Bücherei (in German)

Bergmann H-H, Klaus S, Müller F, Scherzinger W, Swenson JE, Wiesner J (1996) Die Haselhuhner. [The Hazel Hen.] Westarp Wissenschaften, Magdeburg, Germany, p 278 (in German)

Bonczar Z (1992) Karpacka populacja jarząbka Bonasa bonasia (L.,1758) i możliwości oddziaływania na nią. [Carpathian population of Hazel Grouse Bonasa bonasia (L.,1758) and possibilities of its management] Ph.D. thesis. Univ Krakow (in Polish)

Bonczar Z, Wróbel R (1990) Diet composition and feeding activity of Hazel Grouse Tetrastes bonasia L. Acta Agrar Silv Ser Zootech 29:3-12

Cattadori IM, Hudson PJ (2000) Are grouse populations unstable at the southern end of their range? Wildl Biol 6:213-218

Creegan HP, Osborne PE (2005) Gap-crossing decisions of woodland songbirds in Scotland: an experimental approach. J Appl Ecol 42:678-687

De Franceschi PF (1994) Status, geographical distribution and limiting factors of Hazel Grouse (Bonasa bonasia) in Italy. Gibier Faune Sauvage Game Wildl 11(Special Number Part 2): $141-160$ 
Dunning JB, Danielsen BJ, Pulliam HR (1992) Ecological processes that affect populations in complex landscapes. Oikos 65: $375-380$

Fahrig L (2003) Effects of habitat fragmentation on biodiversity. Annu Rev Ecol Evol Syst 34:487-515

Fahrig L, Merriam G (1994) Conservation of fragmented populations. Conserv Biol 8:50-59

Fang Y, Sun Y-H (1997) Brood movement and natal dispersal of Hazel Grouse Bonasa bonasia at Changbai Mountain, Jilin Province, China. Wildl Biol 3:261-264

Głowaciński Z (2002) Czerwona lista zwierząt ginących i zagrożonych w Polsce. [Red list of threatened animals in Poland] IOP PAN, Kraków (in Polish)

Glutz von Blotzheim UN (ed) (1973) Handbuch der Vögel Mitteleuropas, vol. 5. Galliformes und Gruiformes. Frankfurt, Akademische Verlagsgesellschaft, p 532 (In German)

Gutzwiller KJ (2002) Applying landscape ecology in biological conservation. Springer, New York

Hanski IA, Gilpin ME (1997) Metapopulation biology, ecology, genetics, and evolution. Academic Press, San Diego

Hordowski J (1999) Ptaki Polskich Karpat Wschodnich i Podkarpacia [Birds of Polsish Eastern Carpathians and Podkarpacie], vol I PteroclidiformesPasseriformes. Bad nad Ornitofauną Ziemi Przem 7:1-186 (in Polish)

Jamrozy G (1991) The occurrence of the Capercaile [Capercaillie] Tetrao urogallus (L.), the Black Grouse Tetrao tetrix (L.), and the Hazel Grouse Bonasa bonasia (L.) in the Polish Carpathians. Przegląd Zoologiczny 35:361-368

Johnsgard PA (1983) The grouse of the world. University of Nebraska Press, Lincoln, p 410

Johnson JB, Omland KS (2004) Model selection in ecology and evolution. Trends Ecol Evol 19:101-108

Kajtoch Ł (2002) Awifauna Pogórza Wielickiego i Podgórza Bocheńskiego-zagrożenia i propozycja ochrony. [Avifauna of Wieliczka and Bochnia Foothills-threatens and proposition of protection]. Chrońmy Przyr Ojcz 58:38-54 (in Polish)

Kajtoch Ł, Piestrzyńska-Kajtoch A (2006) Awifauna środkowej części Beskidu Wyspowego-propozycje ochrony. [Avifauna of central part of Beskid Wyspowy Mts.-proposition of protection]. Chrońmy Przyr Ojcz 62:33-46 (in Polish)

Kajtoch Ł, Matysek M, Skucha P (2011) Kuraki leśne Tetraoninae Beskidów Wyspowego i średniego oraz przyleglych pogórzy. [Forest grouse Tetraoninae of Beskid Wyspowy and Beskid średni Mountains and adjacent foothills]. Chrońmy Przyr Ojcz 67:27-38 (in Polish)

Keller V, Zbinden N, Schmid H, Volet B (2001) Rote Liste der gefährdeten Brutvogelarten der Schweiz. BUWAL-Reihe Vollzug Umwelt. Bundesamt für Umwelt, Wald und Landschaft, Bern, und Schweizerische Vogelwarte, Sempach

Klaus S, Bergmann HH (2004) Situation der waldbewohnenden Raufusshuhnarten Haselhuhn Bonasa bonasia und Auerhuhn Tetrao urogallus in Deutschland-Oekologie, Verbreitung, Gefaehrdung und Schutz. [Current status of the woodland grouse Hazel Grouse Bonasa bonasia and Capercaillie Tetrao urogallus in Germany-ecology, distribution, threats, and conservation]. Volgewelt 125:283-295 (in German with English abstract)

Klaus S, Sewitz A (2000) Ecology and conservation of Hazel Grouse Bonasa bonasia in the Bohemian Forest (Sumava, Czech Republik). In: Proceedings of the international conference on tetraonids - tetraonids at the break of the millennium. Ceske Budejovice, Czech Republic, 24-26 March 2000, pp 138-146

Kondracki J (2000) Geografia regionalna Polski [Regional geography of Poland]. PWN, Warszawa (in Polish)

Kucera VL (1975) Verbreitung und Populationsdichte von Auerhuhn (Tetrao urogallus), Birkhuhn (Lyrurus tetrix) and Haselhuhn
(Tetrastes bonasia) im westlichen Teil von Sumava (CSR). Orn Mitt 27:160-169 (in German with English summary)

Lepš J, Šmilauer P (2003) Multivariate analysis of ecological data using CANOCO. Cambridge University Press, Cambridge

Lidicker WZ (2002) From dispersal to landscapes: progress in the understanding of population dynamics. Acta Theriol 47:23-37

Martyka R, Skórka P, Wójcik JD, Majka K (2002) Ptaki Ziemi Tarnowskiej [Birds of Tarnów Region]. Not Ornitol 43:29-48 (in Polish)

Montadert M, Leonard P (2006) Post-juvenile dispersal of Hazel Grouse (Bonasa bonasia) in an expanding population of the southeastern French Alps. Ibis 148:1-13

Müller D, Schröder B, Müller J (2011) Modelling habitat selection of the cryptic Hazel Grouse Bonasa bonasia in a montane forest. J Ornithol 150:717-732

Opdam P, Van Dorp D, Brank CJF (1984) The effect of isolation on the number of woodland birds in small woodlots in the Netherlands. J Biogeog 11:473-478

Pulliam HR (1988) Sources, sinks, and population regulation. Am Nat 132:652-661

R Development Core Team (2010) R: A language and environment for statistical computing. $\mathrm{R}$ foundation for statistical computing, Vienna, Austria. ISBN 3-900051-07-0. http://www.R-project.org/

Reed DH (2004) Extinction risk in fragmented habitats. Anim Conserv 7:181-191

Rhim S-J (2006) Home range and habitat selection of Hazel Grouse Bonasa bonasia in a temperate forest of South Korea. For Ecol Manag 226:22-25

Rhim S-J (2010) Spring-season social organization of the Hazel Grouse (Bonasa bonasia) in relation to habitat type in temperate forests of South Korea. Ornis Fennica 87:160-167

Rolstad J (1991) Consequences of forest fragmentation for the dynamics of bird populations: conceptual issues and the evidence. Biol J Linn Soc 42:149-163

Rudner M (2004) LR-Mesh—response surfaces for logistic regression models. Computer program, version 1.0.5. Available from http://www.uni-oldenburg.de/landeco/21343.html

Saari L, Ảberg J, Swenson JE (1998) Factors influencing the dynamics of occurrence of the Hazel Grouse in a fine-grained managed landscape. Conserv Biol 12:586-592

Sachot S, Perrin N, Neet C (2003) Winter habitat selection by two sympatric forest grouse in western Switzerland: implications for conservation. Biol Conserv 112:373-382

Schaublin S, Bollmann K (2011) Winter habitat selection and conservation of Hazel Grouse (Bonasa bonasia) in mountain forests. J Ornithol 152:179-192

Scherzinger W (1976) Raufuss-Hühner, H 2. Schr Nationalpark Bayer Wald, Grafenau

Schumaker NH (1996) Using landscape indices to predict habitat connectivity. Ecology 77:1210-1225

Storch I (2000) Conservation status and threats to grouse worldwide: an overview. Wildl Biol 6:195-204

Sun Y-H, Piao Z-J, Swenson JE (2003) Occurrence of Hazel Grouse Bonasa bonasia in a heavily human-impacted landscape near the Changbai Mountains, northeastern China. Wildl Biol 9:371-375

Swenson JE (1991a) Is the Hazel Grouse a poor disperser? Trans Congr Int Union Game Biol 20:347-352

Swenson JE (1991b) Evaluation of a density index for territorial male Hazel Grouse Bonasa bonasia in spring and autumn. Ornis Fennica 68:57-65

Swenson JE (1993a) Hazel Grouse (Bonasa bonasia) pairs during the nonbreeding season: mutual benefits of a cooperative alliance. Behav Ecol 4:14-21

Swenson JE (1993b) The importance of alder to Hazel Grouse in Fennoscandian boreal forest: evidence from four levels of scale. Ecography 16:37-46 
Swenson JE (1995) Habitat requirements of Hazel Grouse. In: Proceedings of 6th international grouse symposium, pp 155-162

Swenson JE, Danielson J (1991) Status and conservation of Hazel Grouse in Europe. Ornis Scand 22:297-298

Taylor PD, Fahrig L, Henein K, Merriam G (1993) Connectivity is a vital element of landscape structure. Oikos 66:571-573

Watling JI, Donnelly MA (2006) Fragments as islands: a synthesis of faunal responses to habitat patchiness. Conserv Biol 20:1016-1025

Wiesner J, Bergmann HH, Klaus S, Müller F (1977) Siedlungsdichte und Habitatstruktur des Haselhuhns (Bonasa bonasia) im Waldgebiet von Bialowieza (Polen). [Population density and habitat structure of the Hazel Hen (Bonasa bonasia) in the woodlands of Bialowieza (Poland)]. J Ornithol 118:1-20 (in German with English summary)

Wiltowski J (1966) Rozmieszczenie i liczebność jarząbka Tetrastes bonasia (L, 1758) w południowej Polsce w roku 1966
[Distribution and abundance of Hazel Grouse Tetrastes bonasia (L, 1758) in southern Poland in 1966 year]. Acta Zoologica Cracoviensis 11, Kraków (in Polish)

Zbinden N (1979) Zur Okologie des Hazelhuhns Bonasa bonasia in den Buchenwaldern des Chasseral, Faltenjura. [To the ecology of the Hazel Grouse Bonasa bonasia in the Buchenwaldern of the Chasseral, fold law]. Ornithol Beobachter 76:169-214 (in German with English summary)

Żmihorski M (2011) Forest inventory data reveal stand history from 115 years ago. Ann Bot Fennici 48:120-128

Żmihorski M, Chylarecki P, Rejt Ł, Mazgajski TD (2010) The effects of forest patch size and ownership structure on tree stand characteristics in a highly deforested landscape of central Poland. Eur J For Res 3:393-400 